\title{
Recommendations for Secondary Confinement for Detritiation
}

by

D. W. Howard

Westinahouse Savannah River Combanv 


\section{DISCLAIMER}

This report was prepared as an account of work sponsored by an agency of the United States 


\section{DISCLAIMER}

Portions of this document may be illegible electronic imaae products. Images are 
INTER-OFEICE MEMORANDUM

Savannah River site

x-..te an 1000 


\section{DISCUSSION}

nrer a neriod of more than 50 years, operation of non- 
persuasive argument can be made that less than $1000 \mathrm{Ci}$. is at riak nf release. 

recovery of tritium, but purification of the heavy water, 